Fecha de recepción: marzo 2020 Fecha de aceptación: abril 2020 Versión final: junio 2020

\section{Heroines of the Panama Canal: U.S. nurses in the Panama Canal Zone 1880-1914}

Heather McCrea ${ }^{(1)}$

\begin{abstract}
This essay highlights the critical contributions of the Sisters of Charity throughout the French construction of the Panama Canal between 1880 and 1904 and American-trained nurses during the US canal-building until 1914. The Sisters of Charity mended hundreds of thousands of injured and ill immigrant laborers in the Zone. Still, when American-trained nurses arrived in 1904, the nurses found themselves in conflict with the Daughters of Charity, who refused to vacate the hospital they helped found. I argue, self-aggrandizing stories of male accomplishments in the Panama Canal Zone subordinated female participation in one of the largest engineering feats undertaken in modern history. On the front-lines, female caretakers in the Zone understood the risks they faced with a population of transient engineers, scientists, tourists, and entrepreneurs. Even with a limited amount of power, the Sisters of Charity and US nurses made demands of their superiors based on dangers associated with living and working in a "tropical" region. Aware of their power -albeit limited- US nurses developed strategies for survival in the isthmus to protect themselves with limited access to medical supplies and funds.

No matter how small the power nuns and nurses exercised in the Zone, many of their male superiors worried. They worried; what if nurses wanted more pay? What if they refused to work or left? US nurses also fell victim to prevailing stereotypes centered on what "type" of a woman left her home and family to live in the "wilds" of Central America? In US print media, popularized perceptions about nurses abroad came steeped in eugenic-inspired views of gender roles and "fitness." Did nurses in the Canal Zone push gender norms in ways not possible in the US? Furthermore, how did US Canal Zone employees and administrators view nurses? With respect? Ridicule? Have only contemporaries recognized nuns and nurses women for their hard work? Were US Zone nurses valued as heroines throughout the construction of the canal? Or were they only heralded as heroines well after canal construction ended?
\end{abstract}

Keywords: Panama Canal - Daughters of Charity - nurses - public health.

[Abstracts in spanish and portuguese on the pages 243-244]

${ }^{(1)}$ Dr. Heather L. McCrea is an Associate Professor and the Kenneth S. Davis Chair in History. Dr. McCrea is the author of Diseased Relations: Epidemics, Public Health, and State-Building in Yucatán, Mexico, 1847-1924 (University of New Mexico Press, 2010); “Tentative Testimonies: Indigenous and Spanish Accounts of the Conquest 
and Colonization of New Spain 1100-1650," Louise Breen (ed.), Converging Worlds: Communities and Cultures in Colonial America (Routledge Press, 2011); "From Pest to Vector: Disease, Public Health and the Challenges of State-Building in Yucatán, Mexico, 1833-1922" Martha Few and Zeb Tortorici (Eds.), Centering Animals in Latin American History (Duke University Press, 2013).

"How terrible, my dear sister, is the power of these men, who pry into the most secret recesses of our hearts, and endeavor to turn our innocent thoughts in such a direction, as to minister to their based ends. And I fear with good reason, that in some instances they have succeeded." 1

"It was hard to take care of those big wards of fifty patients all tucked inside those cotton bed nets, and some of the men would smoke and then burn holes in the nets." Nurse Bidwell, Panama Canal Zone, 1910. ${ }^{2}$

French diplomat and engineer, Count Ferdinand de Lesseps arrived in Panama in 1881 to begin construction on a trans-isthmian canal. ${ }^{3}$ De Lesseps, however, gained no triumph for the French. He never finished digging the "big ditch" to connecting Atlantic and Pacific oceans. ${ }^{4}$ De Lesseps enjoyed success with the construction of the Suez Canal in the 1860s, but his confidence may have undermined his preparedness for the "tropical" environment and diseases of the Isthmus. Financial mismanagement, disease, and natural disasters left the French Canal Company broke by 1889 having sunk more "nearly $300,000,000$ on the canal. ${ }^{5}$ By the time de Lesseps left the Isthmus in the 1890 s, "roughly seven thousand of the thirteen thousand [employees were] left stranded by the financial collapse."' French Canal Company records show over a six-year period between 1883 and 1889, "over 5,000 deaths occurred in the hospital; 1,200 of which were from yellow fever." ${ }^{\prime}$ Under the supervision of Ferdinand de Lesseps, staggering death tolls earned de Lesseps the moniker the "pall-bearer of Panama."

When de Lesseps began construction on the canal in 1881, a company of French-based nuns, the order of the Daughters of Charity of St. Vincent de Paul had already gained a toehold in the region as caretakers of the poor. ${ }^{9}$ The Daughters of Charity, also known as the "Grey Nuns" because of the blueish-grey color of their clothing and their "big white, winged coif...had earned their order the affectionate name 'God's geese."'10 The Daughters of Charity of St. Vincent de Paul, unlike other religious orders renewed their vows annually prioritizing confraternity in their mission to help the poor. ${ }^{11}$ Wherever the "far-flung" nuns worked they oversaw alms houses, schools, clinics, hospitals, orphanages, and pharmacies. ${ }^{12}$ 
Whether in service to the poor or medical science, women's work in the Canal Zone mattered. From the vantage point of Zone nuns and nurses, any compensation or reward they received did not factor in the challenges they faced navigating environmental obstacles and the risks they took working in the direct path of deadly diseases. Environmental conditions, inside and outside the workplace, and inequitable compensation for their labor dominated the relationships between caretakers and their superiors. Despite the essential services the Daughters of Charity and US-trained nurses provided during Canal construction their stories are still marginalized.

This essay addresses, in part, this sidelining from historical scholarship by piecing together the experiences of nuns and nurses in the Canal Zone from canal reports, government and personal correspondence, and print media. To date, little scholarship singularly focuses on the key role female caretakers played in completion of the Panama Canal in 1914. Patricia Lefevere, in the National Catholic Reporter wrote the history of, "[n]uns' work has remained largely invisible or been deemed inconsequential." ${ }^{13}$ Methodologically, this work investigates the lives of nuns and nurses while they coped with significant challenges stemming from work in "tropical" environments and institutionalized inequity. The omission of female narratives from the history of the canal construction begs the question was their work acknowledged? Or were the contributions of nuns and nurses subordinated to male-generated narratives highlighting impressive modernizing schemas? Julie Green recognizes the role civilian nurses played in canal construction in, The Canal Builders: Making America's Empire at the Panama Canal $(2009)^{14}$ while Sioban Nelson's Say Little, Do Much: Nurses, Nuns, and Hospitals in the Nineteenth Century (2001) explores how "vowed women" (nuns, sisters, deaconesses) a collective identity may have strengthened their success, provided opportunities to demand better wages, work conditions, and housing. ${ }^{15}$ Maureen Fitzgerald's, Habits of Compassion: Irish Catholic Nuns and the Origins of New York's Welfare System, 18301920 outlines a history of charity in conjunction with US immigration, tensions between Protestant and Progressive reformers, and Irish Catholic nuns. ${ }^{16}$ My work builds on this existing scholarship by examining the lives of nuns and nurses -as much as possibleapart from the intricacies of canal construction and grand engineer feats. ${ }^{17}$

The conditions under which Canal nurses worked, slept, and organized recreational events were created by men and ruled over by men. Changing gender roles of the early twentieth century created an opportunity though for some of the Canal Zone nurses to agitate. For instance, the tensions between nurses and nuns and their male superiors, I argue, are emblematic of wider-reaching social tropes aligning men exclusively with modernity and by extension new developments in industrial agriculture, medicine, public health, and medical technology.

Grandiose hero narratives touting the accomplishments of male "doctors in white" should assume some responsibility for sidelining women's contributions to the construction of one of the largest, most ambitious, and costly engineering endeavors in US history. ${ }^{18}$ Stories extolling the accomplishments of men like US Surgeon General William C. Gorgas have obscured the important role nuns and nurses played in supporting a healthy workforce for a behemoth digging project. ${ }^{19}$ Colonel Gorgas' efforts as Chief Sanitary officer for Zone, eventually curbed the spread of yellow fever and malaria on the 
isthmus. ${ }^{20}$ Praise for Gorgas and his accomplishments assumed contours like religiousbased faith or hero-worship. ${ }^{21}$ In an editorial for the The Sun, a Zone nurse wrote, "I believe that the general faith in Col. Gorgas is the only thing that keeps any of us on isthmus."22 The editorial suggests a type of hero-worship for Gorgas had moved beyond the Zone reaching US news outlets. Very few narratives elevate the accomplishments of female caretakers to levels on par with men working in the Canal Zone. Nuns and nurses of the Zone endured what many scientists of the late nineteenth and early twentieth centuries labeled an "insalubrious" "tropical" environment. ${ }^{23}$ Understandably, nuns and nurses worried about contracting one of the many deadly "tropical" diseases slithering across the isthmus.

Relationships between the Daughters of Charity, the US Canal Commission, and the Panamanian government changed with the separation of the Isthmus of Panama from Colombia in $1903 .^{24}$ Religious orders like the Daughters of Charity however held no allegiance to nation-states and so no conflict in continuing their work in Panama and they certainly had no intention of leaving their hospital. As their vows mandated, the Daughters were only bound to the poor, not the French, the US, or the Panamanian government. ${ }^{25}$ The Daughters of Charity were not alone in thinking the US Canal Commission would supply job security for former employees of the French Canal Company including migrant laborers, engineers, scientists, and physicians. From the standpoint of the US Canal Commission though, the French Catholic nuns did not belong in the Zone. Canal commissioners agreed, the nun "issue" required resolution before US nurses arrived. Disinclined to interfere, Panamanian statesmen left negotiations to the Sister Superior and the Governor of the Canal Zone at the time Major General George Whitefield Davis. ${ }^{26}$

Correspondence between canal officials and the executive director of Ancón Hospital verify Canal officials and hospital administration urged the nuns to leave all Canal buildings including Ancón Hospital. ${ }^{27}$ Canal Zone officials complained the Daughters were particularly unruly and often organized strikes demanding more beds and supplies. ${ }^{28}$ The strikes and demands of the nuns however, carved out new spaces for negotiation between caregivers and their superiors. US nurses arriving in 1904 took advantage of cracks in the wall made by the radical nuns to rally for better pay and working conditions as promised in US government advertisements.

The Canal Commission desperately needed nurses, the nuns had dispersed, some stayed but most left the Zone. Canal digging required access to inexpensive and healthy pools of laborers. ${ }^{29}$ Hiring nurses helped safeguard the health of laborers and a bonus for the Canal Commission; nurses cost less to hire than doctors. Advertisements for nursing positions in the Canal Zone drew on a young woman's desire for adventure in exotic lands. Advertisements promised nurse-recruits good pay, clean living quarters, healthy food, and plenty of sunshine. ${ }^{30}$ Louise C. Bidwell responded to one such advertisement in a DC newspaper and by 1904 she had packed her bags and left on a United Fruit Company steamer for Panama. Bidwell likened Panama to the "wild west" with a flurry of prospectors, investors, migrant laborers that flocked to California during the gold rush of 1848. Seduced by print media advertisements other nurses, like Bidwell, traveled to Panama not fully understanding the hardships they would face, the lure of excitement 
was too great "[t]the love of adventure is strong in the young, and the pull of the tropics on the native of the north is powerful."31

Most nurses like Bidwell arriving in the Panama Canal Zone worked at Ancón Hospital. When Bidwell and her fellow nurses entered the hospital, they found a hospital packed with 40,000 workmen who rotated in and out daily. Bidwell complained the "boys" in the Zone, showed truly little respect for nurses. In her correspondence home, Bidwell commented how odd she found newspaper headlines from the clippings her family sent. Bidwell knew firsthand the articles declaring yellow fever and malaria under control or eradicated were wrong. Similarly, images of nurses playing sports and enjoying leisure time on wraparound porch of their fine living quarters did not reflect the reality in which she lived. A reality where having a burro to help haul clothing, water, and other supplies was an absolute necessity. Rain, mud, humidity, and mosquitos presented challenges not expected. ${ }^{32}$

Nurses in the Zone wrote to the Canal Governor's office demanding higher pay for a job in which they fell ill often, endured blistering heat and humidity, fought off swarms of hungry, parasite infected mosquitos, one Canal engineer reported to The Times Democrat, " $[\mathrm{t}]$ he climate is not good here, but any man with a fair constitution and endowment of nerve can stand it well...." ${ }^{33}$ These conditions, they reasoned, merited higher pay. Nurses had every reason to demand more, indeed life in the "tropics" could be perilous for the unacclimated. Pseudoscientific theories asserting the "white race" could not thrive in the "tropics" fortified the nurses' position on risk. Francis Child Nicholas' 1903 travel narrative Around the Caribbean and across Panama reinforces the environmental dangers of life in the "tropics," with descriptions of strange odors emanating from swamps and forests and a "damp heat" that "settles oppressively." ${ }^{44}$ Another report from a traveler asserted Panama "... is, perhaps, one of the most notoriously unhealthy in the world" and "[m]ental deterioration in the tropics has long been known as a form of exhaustion from which there is recovery upon removal to cooler latitudes." ${ }^{35}$ Thomas Wright Jackson, a lecturer on tropical medicine at Jefferson Medical College in Philadelphia and Assistant Surgeon for US Volunteers, tried to ready nurses for work in the "tropics." His advice? The nurses needed "[s]unlight, abundant fresh air, and ventilation." Jackson's theory about the importance of sunlight in healing the sick worked at cross purposes with his counsel for blonde-haired people to avoid direct sunlight. ${ }^{36}$

The nurses of the Zone drew upon racially determinist theories claiming certain "races" flourished in one landscape but withered in another Zone to strengthen their argument about the risks took living and working in the "tropics." Not swayed by the nurses' claims, Zone administrators responded with travel restrictions; no nurse could leave the Zone without explicit and documented permission. These new limitations further strained relations between Zone supervisors and nurses. Tense negotiations surfaced when Canal Zone nurses could not convince their superiors to raise salaries. The nurses pressed further underscoring how their daily battles with heat, humidity, rainy seasons, and mosquitoes merited more compensation. ${ }^{37}$

Indirectly, depictions of nurses in US newspapers did little to endear readers to support their cause. News articles played upon stereotypes of nurses either as saints or defiant "loose" women who refused to conform to gender norms. On one end of the spectrum nurses were in demand and their skills essential. On the other, these articles invalidated and 
undermined their work in the Zone by focusing on appearance, calling them "ugly" and judging them by a presumed inability to fetch a suitable husband. Other articles emphasized only "young and sturdy" women who wanted "adventure" should apply; "homely" nurses were the best choices as the pretty ones tended to marry too quickly. ${ }^{38}$

By the time the Panama Canal opened in 1914, the exodus of US nurses was well underway. No longer eager to gain experience, show off skills, many of nurses had their fill of the "exotic" lands and peoples after two years. Nurses who headed home encouraged others to do the same. Two nurses who had spent about a year working in the Canal Zone returned home and reported they were "very glad to be back again." The nurses told harrowing stories " $t$ the supply of nurses... is beginning to fall off and by fall the hospitals will be very short-handed." According to another passenger on the same ship as the nurses, things were quite bad in the Zone with measles, black measles, smallpox, yellow fever, Chagres fever, and malaria, and there was one case of bubonic plague. The "dead train" the passenger explained "runs from Colon to Monkey Hill Cemetery, a mile and a half south of Colon, always once, and sometimes as often as fourteen times a day." Interviews with passengers provided more alarming information, there is so much yellow fever about that they keep ten graves always ready for cases of emergency." ${ }^{39}$

One year after the Canal opened a special report from the US sanitary Commission in Panama declared, "[t]he habits of the people are in general mostly uncleanly and the sanitary condition is bad. Yellow fever, remittent bilious, and pernicious fevers are endemic." ${ }^{40}$ Effectively redirecting responsibility for sanitation problems from the US Canal Commission to the Panamanians. Yellow fever continued to menace the Canal Zone and surrounding communities long after construction ended.

The stigma of Panama as a yellow fever-riddled region also endured. Writing in 1919, US-born Methodist missionary George A. Miller's Prowling About Panama harps on the topic of stagnate air in the "tropics" calling it "terrifying." After spending an evening with locals working in the Panama Canal Zone he complained with "some primitive prejudice comes a violent dislike of fresh air, especially at night, when every room is as nearly as possible hermetically sealed. In a tropical temperature no one has yet explained how the inmates live till morning." 41 Such descriptions of Panama and other "tropical" zones reinforced existing tropes labeling "tropical" lands and peoples as uncivilized and resistant to modernization. The disconnect between public belief of nurses and the reality of their work conditions also endured. In 1922 a nurse from Minnesota, known only as O.M.B., explained patients regarded nurse-work, “...too easy; they are not earning their money..." In response the Minnesota nurse groused, "Oh! you wizards with the adding machine, -all you great army of workers, even ye street sweepers and the dish washers, -don't envy the trained nurse." ${ }^{42}$ The Minnesota nurse captured some of the sentiments expressed by Zone nurses in their demands for higher pay and better living conditions; value and respect their work. However, it is difficult to reconcile the gaze of outsiders with the experiences of nurses coping with environmental challenges and workplace inequities. 


\section{Conclusion}

How has invisibility shaped the lives of nuns and nurses in historical contexts? Did their invisibility take root in their own time? Or was this invisibility only noted by contemporary scholars? Nurses and nuns provided essential medical aid throughout the construction of the Panama Canal but the stories of female caretakers, some with littleto-no experience remain adjacent to the lives and experiences of other historical actors. Scholars like Julie Green have pointed to a lack of praise for women's work during Canal construction. Contemporary tributes however do not always represent women's work in a reasonable light, casting female caretakers in an overly romanticized light perpetuating constructed narratives.

The Daughters of Charity and US-trained nurses put themselves in harms-way working in the Canal Zone for distinct reasons. The Daughters of Charity labored in service to the poor while US nurses expected compensation. Nuns and nurses however, assumed similar risks while working in the Canal Zone connected to environmental hazards and workplace discord. The Daughters of Charity and the US nurses made demands of their superiors and in each instance they lost. The nuns were expelled from the Canal Zone when the Americans took over and US nurses failed to secure higher wages thus many chose and return home. What emerges from the combined experiences of nuns and nurses in the Canal Zone is a fractured and incomplete narrative replete with contradictions. However flawed, the narrative mirrors the decentralized, male-dominated structures in which the nuns and nurses worked. Historically, the lives of female caretakers in the Canal Zone have been constructed only in relation others. Only after the canal project ended did nuns and nurses garner widespread respect for their work in the Zone.

\section{Notes}

1. Josephine M. Bunkley, The Escaped Nun, Or Disclosures of Convent Life; and the Confessions of a Sister of Charity. Giving. A More Minute Detail of Their Inner Life, and a Bolder Revelation of the Mysteries and Secrets of Nunneries, Than Have Ever Before Been Submitted to the American Public, (New York: De Witt \& Davenport, Publishers, 1855), 65.

2. Wichita State University (WSU), Ablah Library and Special Collections, Louise C. Bidwell Collection, MS 86-13, folder 4.

3. Panama was part of the republic of Colombia until 1904.

4. Noel Maurer and Carlos Yu, The Big Ditch, (Princeton University Press, 2010)

5. Robert J. Swain C. M., "A History of the American Vincentian Fathers in Panama," Vincentian Heritage Journal, 3:1 1982, 45; "Affairs in the Canal Zone: The exodus from the Isthmus and its Causes: Discontent Among Canal Employees One Problem of Building Canal-Not an Undue Amount of Sickness-Administrative Methods Criticized Severely," NLM, Canal Commission Books, collection of articles, clippings, and letters on health in the Panama Canal Zone, 5 volumes, Volume 5 (1880-1915) WA, 900 DP3, C6, 15. 
6. Maurer and Yu, The Big Ditch, (2010) 115.

7. Colonel F. H. Hess, Medical Corps, USA, Superintendent, Ancón Hospital, "Ancón Hospital, Ancón, Canal Zone" (Reprint from Surgery, Gynecology and Obstetrics (October 1920) 424-429.

8. Clifford Krauss, Inside Central America, Its People, Politics and History (New York: Simon and Schuster, 1991, 251.

9. Carol K. Coburn and Martha Smith, Spirited Lives: How Nuns Shaped Catholic Culture and American Life, 1836-1920 (Chapel Hill: University of North Carolina Press, 1999), 19. The Daughters of Charity were one of the first Catholic communities to appear in the early years after the Reformation.

10. Carol K. Coburn and Martha Smith, Spirited Lives: How Nuns Shaped Catholic Culture and American Life, 1836-1920 (Chapel Hill: University of North Carolina Press, 1999), 19; David McCullough, The Path Between the Seas: The Creation of the Panama Canal 18701914, (Simon \& Schuster, 1978), 172.

11. The Daughters of Charity of St. Vincent de Paul were formally recognized in the early 17th century France. For more information on the history of the Catholic religious orders see: M. Dennis and Moe-Lobeda J. Nangle, St. Francis and the foolishness of God (C. \& S. Taylor, 1993); Medical Mission Sister, Medical Mission Sisters Committed to Health and Healing (Philadelphia Author, 1994).

12. Susan E. Dinan, Women and Poor Relief in Seventeenth-Century France: The Early History of the Daughters of Charity, [Ashgate, 2006] (Routledge, 2017), 144; B. Randolph, "Sisters of Charity of St. Vincent de Paul," The Catholic Encyclopedia (New York: Robert Appleton Company, 1908). http://www.newadvent.org/cathen/03605a.htm. The Order of Occupations of the Daughters of Charity of St. Vincent de Paul constituted one of the many religious orders, philanthropic agencies, and scientists present in the Canal Zone under French authority. With bases in France and Canada, the Daughters of Charity were active in Nova Scotia, Halifax, New York and Latin America and the Caribbean.

13. Patricia Lefevere, "Historian shines light on US sisters' contributions," National Catholic Reporter, 46:9, 1.

14. Julie Green, The Canal Builders: Making America's Empire at the Panama Canal, (Penguin Books, 2009), 227. Also see; Jorge Giovannetti and Reinaldo Roman (eds.), "Garveyism in the Hispanic Caribbean," special issue, Caribbean Studies 31:1 (2003) 1-259; Anne Macpherson, "Colonial Matriarchs: Garveyism, Maternalism, and Belize's Black Cross nurses, 1920-1952," Gender and History,15:3, 507-27.

15. Sioban Nelson, Say Little, Do Much: Nurses, Nuns, and Hospitals in the Nineteenth Century (University of Pennsylvania Press, 2001).

16. Maureen Fitzgerald, Habits of Compassion: Irish Catholic Nuns and the Origins of New York's Welfare System 1830-1920 (University of Illinois, 2006); Kathleen Sprows Cummings, A Saint of Our Own: How the Quest for a Holy Hero Helped Catholics Become American (The University of North Carolina Press, 2019).

17. The digital portal/blog for the Vieja Escuela de Panama, "La labor de la mujer en los trabajos de construcción del Canal de Panamá," offers a clear framework for understanding women's work during the construction of the Canal. Also see, Martha M. Libster 
and Sister Betty Ann McNeil, Enlightened Charity: The Holistic Nursing Care, Education, and Advices Concerning the Sick of Sister Matilda Coskery, 1799-1870 (Golden Apple Publications, 2009); Margaret M. McGuinness, (New York University Press, 2013).

18. "Red Take at Panama. How Uncle Sam Loses $\$ 20,000$ a Day While Congress Haggles Over Prices of Waffle Irons and Muffin Times," The Boston Globe, Sunday 23, 1905, 3.

19. In 1914, the National Academy of Sciences awarded William C. Gorgas and George Washington Goethals the Public Welfare Medal. Goethals trained as a civil engineer and in 1907 US President Theodore Roosevelt appointment Goethals the first Governor of the Canal placing him in charge of construction and opening of the Panama Canal, see Joseph Buchlin Bishop, Goethals-Genius of the Panama Canal-A Biography (Bishop Press, 2007). William C. Gorgas was a US Army Physician and the 22nd Surgeon General of the US Army between 1914 and 1918. Among his many achievements in medicine, Gorgas served as the chief sanitary officer for the Panama Canal project and implemented far-reaching sanitary programs including fumigation, use of mosquito netting, and construction of public water systems, see Willard H. Wright, 40 Yeas of Tropical Medicine Research: A History of the Gorgas Memorial Institute of Tropical and Preventative Medicine, inc. and the Gorgas Memorial Laboratory (Baltimore, Reeves Press, 1970).

20. National Library of Medicine (NLM), Canal Commission Books, collection of articles, clippings, and letters on health in the Panama Canal Zone, 5 Volumes, Vol. 5 (1880-1915) WA, 900 DP3, C6, (pagination is inclusive to the collection), "Improved Sanitary Conditions in the Canal Zone," 23.

21. Benjamin Kidd, The Control of the Tropics (New York: The Macmillan Company, LTD, 1898); Glenn Scott Allen, Master Mechanics and Wicked Wizards: Images of the American Scientist as Hero and Villain from Colonial Times to Present (University of Massachusetts Press, 2009).

22. NLM, Canal Commission Books, collection of articles, clippings, and letters on health in the Panama Canal Zone, 5 Volumes, Vol. 5 (1880-1915) WA, 900 DP3, C6, "The Men in the Zone. How Our Fine Fellow Are Working There-Give 'Em Sympathy and More Pay!" 24.

23. The terms the "tropics" and "tropical" carry with it discourses specific to time and place. The "tropics" is also a word laden with reductionist thought and stereotypes persist to this day. The notion of a "tropical" paradise sits across from the ideas that "temperate" regions were more healthful making the "tropics" are inherently dangerous and insalubrious places.

24. The 1904 "Taft Agreement" secured Isthmian independence from Colombia, provided business elites with more autonomy over their investments, and guaranteed US rights to build the canal and occupy the Zone for the next ninety-nine years.

25. "Organized Charity," The Irish Standard (Minneapolis), 16 December, 31: 6, 4.

26. Merrill Edwards Gates (eds.), Men of Mark in America: Ideals of American life told in Biographies of Eminent Living Americans, (Washington, DC: 1905) Vol 1, 277-279. A US-trained engineer, Whitefield a veteran of the Civil War, served as the military Governor of Puerto Rico before his appointment as the first military Governor of the Panama Canal Zone. The Canal Commission asserted the land upon which Ancón belonged to 
the US Canal Commission. Under Article XVIII of the US-Panamanian government's 1904 agreement the hospital belonged to the US government.; Article XIX also required the "Comisión de Beneficencia" to pay one Colombian dollar per year for "ground rent." 27. Colonel F. H. Hess, Medical Corps, USA, Superintendent, Ancón Hospital, "Ancón Hospital, Ancón, Canal Zone" (Reprint from Surgery, Gynecology and Obstetrics (October 1920) 424-429.

28. Archivo Nacional de Panamá, Caja 884, tomo 2994, Feb.-Abril 1898, 11-22.

29. University Medical Center Kansas City (UMKC), Clendening Library, Special Collections, Gorgas Hospital, Microfilm Documents, collected and microfilmed by Ora V. Stich, Former Medical Librarian at the Samuel T. Darling Memorial Library, Gorgas Hospital, Panama Canal Zone.

30. "Physicians for the Canal Zone-A Warning," NLM, Canal Commission Books, collection of articles, clippings, and letters on health in the Panama Canal Zone, Vol. 5 (1880-1915) WA, 900 DP3, C6, 3.

31. "Nurses to Panama: Three go from Rossland to the Isthmus," East Oregonian, $14 \mathrm{Au}-$ gust 1905, 8; "Physicians for the Canal Zone-A Warning," NLM, Canal Commission Books, collection of articles, clippings, and letters on health in the Panama Canal Zone, 5 volumes, Volume 5 (1880-1915) WA, 900 DP3, C6, 4.

32. Letter from Miss Bidwell to Miss Mary B. Irwin, January 1910, WSU, Ablah Library Special Collections, Louise C. Bidwell Collection, MS 86-13, folder 4.

33. "Chinese May Dig the Canal: Engineer Says They Make Good Laborers-Exaggerations about Panama," special to The New York Times, Pittsburg, 25 June." NLM, Canal Commission Books, collection of articles, clippings, and letters on health in the Panama Canal Zone, 5 volumes, Volume 5 (1880-1915) WA, 900 DP3, C6, 21.

34. Nicholas, Around the Caribbean (1903), 2.

35. "A Disturbing Theory. We beg leave to call to the attention of the War Department a recent editorial paragraph in American Medicine, a journal of the medical profession published in the Philadelphia. The paragraph follows." "Physicians for the Canal Zone-A Warning," NLM, Canal Commission Books, collection of articles, clippings, and letters on health in the Panama Canal Zone, 5 volumes, Volume 5 (1880-1915) WA, 900 DP3, C6, 22. 36. Jackson, Tropical Medicine (1907), 120.

37. UMKC, Gorgas Hospital, Collected and Microfilmed by former medical librarian at Samuel T. Darling Memorial Library, Gorgas Hospital, Panama Canal Zone, Isthmian Canal Commission, File \#1306, Executive Office, Ancón, September 9, 1904.

38. "Panama Canal Hospital Employment Agency: Only Homely Nurses Wanted Pretty Ones are Married too Quickly," Washington Post, Friday, 13 March 1908.

39. "A 'Dead Train' At Panama: Hospital Nurses Deserting: Three Passengers who Arrived form the Isthmus Held at Quarantine -Supposed to Have Yellow Fever," The Summary, 33:27 (Elmira, New York), 8 July 1905, 1.

40. United States National Library of Medicine (NLM), Office of the Surgeon General, Canal Commission Books, WA, 900, DP3, AC6, 1915 Vol. 1 of 5; 3.

41. George A. Miller, Prowling About Panama (NY: The Abingdon Press, c1919), 207-208. 42. O.M.B. "Little Experiences of a Private Duty Nurse," The American Journal of Nursing, Vol. 23: 2 (Dec.,1922), 222-225; 222. 
Heroínas del Canal de Panamá: Enfermeras de los Estados Unidos de América en la zona del Canal de Panamá entre 1880-1914

Resumen: Este ensayo resalta las contribuciones críticas de las Hijas de la Caridad a lo largo de la construcción francesa del Canal de Panamá entre 1880 y 1904 y también las de las enfermeras entrenadas en EEUU durante la parte norteamericana de la construcción del canal hasta 1914. Las Hijas de la Caridad curaron cientos de miles de heridos y trabajadores inmigrantes enfermos en la Zona. Aún así, cuando las enfermeras entrenadas en Estados Unidos de América llegaron en 1904, ellas se hallaron en conflicto con las Hijas de la Caridad, quienes se negaron a abandonar el hospital al cual ayudaron a fundar. Sostengo que las historias de autoenaltecimiento de los logros masculinos en la Zona del Canal de Panamá subordinaron la participación femenina en una de las mayores hazañas de ingeniería realizadas en la historia moderna. En la primera línea de fuego, las trabadoras de la salud en la Zona entendieron los riesgos que enfrentaban con una población temporaria de ingenieros, científicos, turistas y empresarios. Incluso con una cantidad limitada de poder, las Hijas de la Caridad y las enfermeras de los Estados Unidos de América hicieron demandas a sus superiores basadas en los peligros asociados con vivir y trabajar en una región "tropical". Conscientes de su poder, aunque limitado, las enfermeras estadounidenses desarrollaron estrategias de supervivencia en el istmo para protegerse al tener acceso limitado a suministros y fondos médicos.

No importa cuán poco poder tenían las monjas y enfermeras en la Zona, muchos de sus superiores hombres se sintieron preocupados. ¿Y si las enfermeras quisieran más paga? ¿Qué pasaría si se negaran a trabajar o se marcharan? Las enfermeras estadounidenses también fueron víctimas de los estereotipos predominantes centrados en qué "clase" de mujer deja su hogar y su familia para vivir en las "selvas" de América Central. En los medios impresos de los EEUU, Las percepciones popularizadas sobre las enfermeras en el extranjero se empaparon de puntos de vista inspirados en eugenesia sobre los roles de género y la "aptitud". ¿Las enfermeras en la Zona del Canal cambiaron las normas de género de maneras que no eran posibles en los Estados Unidos? ¿Cómo vieron los empleados y administradores de la Zona del Canal de EEUU a las enfermeras? ¿Con respeto? ¿Ridiculizándolas? ¿Sólo en la actualidad se ha reconocido a las monjas y enfermeras por su arduo trabajo? ¿Se valoró a las enfermeras de la zona estadounidense como heroínas durante la construcción del Canal? ¿ $\mathrm{O}$ sólo fueron consideradas como heroínas mucho después de terminada la construcción del Canal?

Palabras clave: Canal de Panamá - Hijas de la Caridad - enfermeras - salud pública.

\section{Heroínas do Canal do Panamá: Enfermeiras dos Estados Unidos da América no Área do Canal do Panamá entre 1880-1914}

Resumo: Este ensaio destaca as contribuições críticas das Filhas da Caridade em toda a construção francesa do Canal do Panamá entre 1880 e 1904 e também de enfermeiras 
treinadas nos EUA durante a parte norte-americana da construção do canal até 1914. As Filhas de la Caridad curou centenas de milhares de trabalhadores imigrantes feridos e doentes na área. Ainda assim, quando as enfermeiras treinadas nos Estados Unidos da América chegaram em 1904, encontraram-se em conflito com as Filhas da Caridade, que se recusaram a deixar o hospital que ajudaram a fundar. Afirmo que as histórias de auto-glorificação da conquista masculina na Zona do Canal do Panamá subordinavam a participação feminina em um dos maiores feitos de engenharia realizados na história moderna. Na primeira linha de fogo, os profissionais de saúde da Zona entenderam os riscos que enfrentavam com uma população temporária de engenheiros, cientistas, turistas e empresários. Mesmo com uma quantidade limitada de poder, as Filhas da Caridade e as enfermeiras dos Estados Unidos da América fizeram exigências aos seus superiores com base nos perigos associados à vida e ao trabalho em uma região "tropical". Cientes de seu poder, embora limitado, as enfermeiras americanas desenvolveram estratégias de sobrevivência no istmo para se protegerem, tendo acesso limitado a suprimentos e fundos médicos.

Não importava quão pouco poder as freiras e enfermeiras tivessem na Área, muitos de seus homens superiores estavam preocupados. E se as enfermeiras quisessem mais remuneração? O que aconteceria se eles se recusassem a trabalhar ou fossem embora? As enfermeiras americanas também foram vítimas de estereótipos predominantes, focados em que "classe" de mulheres deixa casa e família para viver nas "selvas" da América Central. Na mídia impressa dos Estados Unidos, as percepções popularizadas de enfermeiras no exterior estavam imersas em visões eugenicamente inspiradas de papéis de gênero e "aptidão". As enfermeiras da Zona do Canal alteraram as normas de gênero de maneiras que não eram possíveis nos Estados Unidos? Como os funcionários e administradores da Zona do Canal dos EUA encararam os enfermeiros? Respeitosamente? Ridiculando eles? Freiras e enfermeiras são reconhecidas hoje apenas por seu trabalho duro? As enfermeiras da zona americana foram valorizadas como heroínas durante a construção do Canal? Ou foram consideradas heroínas apenas muito tempo depois que a construção do canal foi concluída?

Palavras-chave: Canal do Panamá - Filhas da Caridade - enfermeiras - saúde pública.

[Las traducciones de los abstracts fueron supervisadas por el autor de cada artículo] 